\title{
Analysis of Violence Against Women Act and the South Asian Immigrants in the United States
}

\author{
Shreya Bhandari
}

\begin{abstract}
The issue of domestic violence among South Asian immigrant population in the United States is examined in the light of the Violence Against Women Act. The paper gives a background to the issue of domestic violence in the South Asian community and examines the Violence Against Women Acts of 1994, 2000 and 2005 with regard to issues affecting South Asian women. It addresses issues around marriage and has emphasized the difficulties of women with dependent immigration status. Policy alternatives are examined and discussed with regard to efficacy and efficiency of the policy.
\end{abstract}

Keywords: South Asian immigrant women, domestic violence, Violence Against Women Act.

Domestic violence cuts across race, religion, countries, class and is a universal phenomenon (Orloff \& Kelly, 1995). A study of 160 South Asian women in heterosexual relationships in Greater Boston revealed that $40.8 \%$ of the women were physically abused and/or sexually abused by their current male partner, $36.9 \%$ of them were reported to be victimized in the past year and $65 \%$ of them reporting physical abuse also reported sexual abuse. The sample was collected through community outreach methods like flyers and snowball sampling (Raj \& Silverman, 2002). About 30 to $50 \%$ of Asian and Latina immigrant women in the U.S face domestic abuse from their intimate partners (Dutton, Orloff, \& Hass, 2000). As per the research by Manavi, a South Asian women’s group, 25$30 \%$ of Asian Indian women in the United States suffer abuse at the hands of their partners at one time or another (Warrier, 2000).

\section{Background}

\section{IMMIGRATION AND VAWA}

This article looks at the issue of domestic violence among the South Asians and the pros and cons of the Battered Immigrant Women Protection Act under the Violence Against Women Act of 2005 in comparison with the earlier Violence Against Women Acts. The South Asian community consists of people from India, Pakistan, Bangladesh, Sri Lanka, Bhutan, Nepal and the Maldives. Due to its friendly laws of immigration, the United States is built on a huge and ever growing immigrant population (Abraham, 2000b). Moreover after the easing of the immigration laws in 1965, a large number of South Asian families started coming to the United States. In the 1960s the South Asians who immigrated to the United States were professionals. This demographic composition changed in the 1990s. The cycle of "chain immigration" started wherein the South Asians who were U.S citizens sponsored their relatives to migrate to the United States. Recently the migration consists of professionals working in the information technology industry (Abraham, 2000b). There has been a sharp growth in the South Asian population from

Shreya Bhandari is a Doctoral Student at the School of Social Work, University of Missouri-Columbia.

Copyright (C 2008 Advances in Social Work Vol. 9 No. 1 (Spring 2008), 44-50. 
1990-2000, more than double than before with Indians being $88 \%$ of the entire South Asian population (U.S Bureau of the Census, 2002).

\section{The Application Process for Residency in the United States}

There were many fraudulent marriages reported among the immigrant population in the 1980s which led to the Congress passing the Immigration Marriage Fraud Amendment (IMFA) in 1986 (Rae, 1988). After the passing of this Act the U.S citizen or the Legal Permanent Resident would have to file for the "conditional resident status" for the dependent spouse. There would be a waiting period of 2 years after which the couple would jointly petition to the Immigration and Naturalization Service (INS) to adjust the conditional residency to permanent residency. The couple would have to undergo a personal interview with the INS to prove that the marriage was not a fraud. The waiting period began from the day conditional status of residency was obtained (Anderson, 1993). It is interesting to note that under the guise of detecting "fraudulent marriages" the INS has made many stringent policies for the application of residency. It did not realize that it is equally important to provide welfare and economic security to legal dependent immigrants as it is to detect the illegal immigrants (Narayan,1995).

Though a lot of South Asian women enter the United States on their own, there are a considerable number of them who enter the country on a dependent status through marriage with a legal permanent resident, U.S citizen or a professional on a wok permit. Women who are already socially, psychologically and economically dependent on their partners become legally dependent on them too because of the IMFA (Abraham, 2000b).

\section{Analysis and Comparison of Violence Against Women Act of 2005 with the earlier Acts on Violence Against Women.}

Until the Violence against Women Act of 1994, the control of the immigration status of the dependent spouse rested on the spouse who was a U.S citizen or a legal permanent resident. Thus, if the husband was abusive the battered woman was rendered without any support (Orloff \& Kelly, 1995).

However the Violence Against Women Act of 1994 offered a big respite. It included the Violent Crime Control and Law Enforcement Act which was passed into law on September 1994. This allowed an alien spouse to do a self petition for unconditional permanent resident status or apply for suspension of deportation (Orloff \& Klein, 1995). With the improvements and changes made in the Act from 1994 to 2000 there has been an increase in the access of services by the battered women (Orloff \& Kaguyutan, 2002).

However for the self petition or suspension of deportation, the woman should have stayed in the United States for 3 years. Even though Violence Against Women Act of 1994 made several provisions in favor of abused women of color, it did not take into account women who experienced abuse within the first three years of marriage. Further the passing of the welfare reform legislation in 1996 denied legal immigrants access to federal, state and local benefit programs. Even if a woman became eligible for welfare benefits, she had to give proofs through police, hospital, social service agencies that she was abused. Hence the complex immigration policies which were discriminatory and not in favor of women increased their vulnerability during violence (Abraham, 2000a; Anderson, 1993). There 
were some groups of battered women like survivors of elder abuse, etc, which were not covered by the Act. Most of the time women did not have their own resources or structural support to attain legal assistance (Orloff \& Kaguyutan, 2002).

There were a few positive introductions made in the Violence Against Women Act (VAWA) of 2000. Two new categories of non immigrant visas were introduced in the VAWA 2000- "T" and "U". "T" visas provides legal status for up to 5,000 victims of sex trafficking and forced labor each year. "U" visas are issued to immigrants who are either victims of or who possess information regarding many forms of criminal activity like rape, domestic violence, and sexual assault. Both the visas provide nonimmigrant status, including work authorization, to the victims and certain family members (NCADV, 1/16/06). There was requirement of extensive documentation that the immigrant women would suffer extreme hardship if deported back to the country. As a result women did not receive approvals of their self-petition cases. It required the help of attorney. With no requirement of documentation to prove extreme hardship if deported back to the home country in VAWA 2000 made it easier for the domestic violence advocates to collect more evidence for other issues in VAWA cases.(Orloff \& Kaguyutan, 2002).

\section{Specific issues related to spouses on dependent visa where the partner is on work permit}

About 3,00,000 visas have been issued to the dependent spouses of " $\mathrm{H}-1 \mathrm{~B}$ " visa holders, which is the "H-4". These women are mostly educated, English speaking, and most of the time have had a rewarding career back home. As per the US immigration laws, they are not authorized to work if they are on a dependent "H4 visa"(workpermit.com, 2005). Thus the legally dependent women land up in a powerless position financially as well. Social isolation adds to the already existing dependency of these women. Thus the legally dependent spouses in this category are left with no options. Hence what is increasingly needed is a space for such immigrant women where they could seek redress if faced with a violent situation. In spite of being from middle and educated class, they are trapped in a "Catch 22" situation. They are not authorized to work or self-petition as their husbands are on temporary visas and hence are dependent on the abuser. So there is no way to escape the abuser.

"H-1 B" sponsorship for these women also becomes difficult as it needs an employer and on several occasions degrees from their countries are not recognized unless from a U.S. university. Moreover getting a student visa is also not easy as the cost of education is very high and the scholarships and grants are mostly available to U.S. citizens. The victim can file a police complaint and apply for U visa, which is meant for crime victims. However immigrant women don't want to get into options of deporting their spouses. However what is needed is that these women should have a right to work and self petition (Shah, 2004).

\section{Features of the Violence Against Women Act (VAWA) 2005}

Title VIII of VAWA 2005 deals with the protection of Battered and Trafficked Immigrants. The Violence Against Woman Act of 2005 has taken care of a number of the above drawbacks in the 1994 and 2000 Act. Even though the 1994 and the 2000 Act had 
worked in the direction to reduce violence against women, there were still several categories of women and children whose lives were at risk. Many of them are still being deported and several others are still trapped by the abusers in life threatening situations (Lin \& Orloff, 2005).

As per section 813 (a) of the Violence Against Women Act and Department of Justice Reauthorization Act of 2005, battery and extreme cruelty are added to the list of exceptional circumstances in deportation proceedings of the abusers. At the same time in section 812 of VAWA Act of 2005 the victims of domestic abuse, sexual assault and trafficking are exempted from sanctions for failing to depart voluntarily. The self petitioning is also extended to the victims of elder abuse where the perpetrators are U.S citizens. It allows child abuse and incest victims to self petition up to age 25. Thus Section 805 (c) of VAWA 2005 protects the abused immigrant children and children of abused immigrants from being cut off from VAWA immigration protection when they turn 21.

The most important leap made by Section 814 (b) of the VAWA 2005 is to provide the spouses entering the United States accompanying or joining the partner on A, E, (iii), $\mathrm{G}$, or $\mathrm{H}$ non-immigrant visa granted work authorization if the spouse demonstrates that during the marriage he or she has been battered or exposed to extreme cruelty [814 (c)]. Employment is authorized for victims with approved VAWA petitions and "T" visas.

There was an amendment in the 2005 Act and Section 104 guaranteed access to legal services for immigrant victims by authorizing any legal services corporation (LSC)funded program to use any source of funding, including LSC funding, to represent any victim of domestic violence, sexual assault, trafficking, or other crime, regardless of the victim's immigration status. As per section 821 (a) and (b) the duration of “T and U” visa has been extended to 4 years (VAWA, 2005).

\section{RECOMMENDATIONS FOR IMPROVING IMMIGRATION POLICIES}

As per section 814 (c) of the VAWA 2005 work authorization is allowed to a immigrant woman on a dependent visa if she faces violence. Her status still depends on that of her spouse as the Act does not allow her to self petition and it does not spell out her status if the husband returns to the home country. Moreover her visa status still remains the same. The alternative would have been to allow these women to self petition so that they are not dependent on the abusers. The leap made by the Violence Against Women Act of 2005 is allowing work authorization if the woman faces violence and not otherwise. This however again puts the onus on the woman as she has to gather proofs to report her abuse to the criminal justice system (Raj, Silverman, McCleary-Sills, \& Liu, 2005). Instead it should allow her to self petition and authorize her to work regardless of whether or not she faces violence.

The Act requires the K(fiancé visa) visa petitioners to disclose criminal background information to the Department of Homeland Security. It states that this would help the government track down serial $\mathrm{K}$ petition filed by the same petitioner (VAWA, 2005). However the Act does not spell out the status of the woman if she does not marry the person who brought her to this country. The law discriminates against women who refuse to marry an abusive fiancé by failing to provide a status for them. The Act should accommodate such women by allowing self-petition and exempting from the penalties for failing to depart if not married within 90 days. 
There should be a new ground for a hardship waiver for conditional residence for abused intended spouses who unknowingly married abusers who were legally married to someone else. Another suggestion is that there should not be a waiver of 5 years for the victims of Violence Against Women Act to receive public benefits. They should have direct access to food stamps and Social Security Insurance (Lin \& Orloff, 2006). The proof of marriage to a U.S Citizen or legal permanent resident and legal entry to the United States should automatically confer the conditional residency to spouses and the couple should not be asked to wait till the application is filed (Narayan, 1995). This will be a step at the preventive level and will not rest the immigration status on the partner who is a resident or a citizen. It will be really helpful to women if they land in violent situations. The entire concept of battered women expected to prove violence becomes difficult as most of the times immigrant women are not able to collect such proofs and it becomes all the more complex when mental cruelty needs to be proven. So the testimony should be gathered from relatives, friends, religious leaders and the woman's testimony should also be sufficient (Narayan, 1995).

\section{ASSESSING THE ALTERNATIVES AND EVALUATIVE CRITERIA}

The policy alternatives are assessed on the basis of equity and effectiveness. Equity has been defined as the extent to which "situations in similar circumstances are dealt with similarly". So a program is considered to be inequitable if two persons are identical in other aspects but receive different treatment from it (Jannson, 1984).

Moreover the United Nations Declaration on the Elimination of Violence Against Women and International human rights laws provide the right to employment and full equality to all under the law (United Nations, Resolution 48/104, 1993). The immigration laws prohibit women from working or changing their visa status- which are the rights guaranteed to their immigrant husbands on work visas. Thus denial of this right leads to denial of basic human rights (Raj et al., 2005). Hence an immigrant woman should also have the right to be in a safe environment and if she is in a violent situation she should have access to resources to redress the violence. Similarly if a woman comes here on a working visa, she will have access to more resources than a woman who is on a dependent visa. Thus the VAWA 2005 does not follow the principle of equity nor does it abide by the United Nations Declaration on the Elimination of Violence Against Women and International human rights laws. Work authorization will not make the immigrant women invulnerable to violence but will give them access to resources if they encounter a situation of violence.

The alternatives should also enable battered women to access the legal services without the help of experts like the legal attorney. The evaluative criteria for the policy alternatives could be known by conducting research studies with South Asian women to measure if the changes brought about in the policy are effective in enabling the women to rebuild their lives.

Moreover research needs to be done to see if the changes made at the policy level in Violence Against Women Act has been utilized by women safely(Raj et al., 2005) . It needs to be assessed if the accessibility of the battered women to the requisite relief services has been made easy especially with the cultural and immigrant barriers. The other 
important criterion is to determine if the policy level change is appropriate, culturally competent and empowering the woman to resist violence.

\section{CONCLUSION}

United States is a country where one in ten is an immigrant and hence knowledge about the policies affecting the immigrant population is necessary for competent social work. Also inclusion of practice with the immigrants within international social work demonstrates the link between domestic and global issues, advocating that there is nothing like local social work in the $21^{\text {st }}$ century (Healy, 2004). By being aware of complex topics like policies for abused immigrant women, social workers can equip themselves if they come across any abused immigrant woman. This article specializes in South Asian immigrant women, however the above information can be used for any abused immigrant woman. Moreover awareness about such issues will also give them greater negotiating power for advocating for progressive policy level changes which will enable the immigrant women to seek relief in the times of violence. All this will help more and more immigrant women and children to live violent free lives. There is a lot of lack of awareness about this issue other than South Asian domestic violence organizations, hence such an article will educate social workers who are at times directly involved with the survivors.

\section{References}

Abraham, M. (2000a). Isolation as a Form of Marital Violence: The South Asian Immigrant Experience. Journal of Social Distress and the Homeless, 9(3), 221-236.

Abraham, M. (2000b). Speaking the Unspeakable: Marital Violence among South Asian Immigrants in the United States: Rutgers University Press.

Anderson, M. J. (1993). License to abuse: The impact of conditional status on female immigrants. Yale Law Journal, 102(6), 1401-1430.

Dutton, M. A., Orloff, L. E., \& Hass, G. A. (2000). Characteristics of Help-Seeking Behaviors, Resources and Service Needs of Battered Immigrant Latinas: Legal and Policy Implications. The Georgetown Journal on Poverty Law and Policy, 7, 245305.

Healy, L. (2004). Strengthening the Link: Social Work with Immigrants and Refugees and International Social Work. In D. Drachman \& A. Paulino (Eds.), Immigrants and Social Work: Thinking Beyond the Borders of the United States.

Jannson, B. S. (1984). Theory and Practice of Social Welfare Policy: Analysis, Processes, and Current Issues. Belmont: Calif: Wadsworth.

Lin, J., \& Orloff, L. (2005). VAWA 2005 Immigration Provisions. Washington, DC: Legal Momentum Advancing Women's Rights.

Lin, J., \& Orloff, L. (2006). Aftermath of VAWA Immigration 2005: What was NOT Included in Final VAWA (H.R.3402). Washington, DC: Legal Momentum Advancing Women's Rights.

Narayan, U. (1995). 'Male-order' brides: Immigrant women, domestic violence and immigration law. Hypatia, 10(1), 104. 
NCADV. (1/16/06). Comparison of VAWA 1994, VAWA 2000 and VAWA 2005 Reauthorization Bill. Retrieved 4/19/2006, 2006, from http://www.ncadv.org/files/VAWA_94_00_05.pdf

Orloff, L., \& Kaguyutan, J. (2002). Offering a Helping Hand: Legal Protections For Battered Immigrant Women. American University Journal of Gender Social Policy and the Law10(1), 95-170.

Orloff, L., \& Kelly, N. (1995). A look at the Violence Against Women Act and gender related asylum. Violence Against Women, 1, 380-400.

Orloff, L., \& Klein, C. F. (1995). With No Place to Turn: Improving Advocacy for Battered Immigrant Women. Family Law Quarterly, 29(2), 313-329.

Rae, K. L. (1988). Alienating sham marriages for tougher immigration penalties: Congress enacts the Marriage Fraud Act. Pepperdine Law Review, 15(1), 181-205.

Raj, A., \& Silverman, J. (2002). Intimate Partner violence against South-Asian women in Greater Boston. Journal of American Medical Women's Association, 57(2), 111116.

Raj, A., Silverman, J., McCleary-Sills, J., \& Liu, R. (2005). Immigration Policies Increase South Asian Immigrant Women's Vulnerability to Intimate Partner Violence. Journal of American Medical Women's Association, 60(1), 26-32.

Shah, S. (2004, 11/28/2004). Trapped, on a 'H-4'. THE HINDU. Retrieved 4/19/2006, 2006, from http://www.hinduonnet.com/thehindu/mag/2004/11/28/stories/2004112800380300. htm

The Violence Against Women Act and Department of Justice Reauthorization Act of 2005 (VAWA) Pub. L. No.109-162, Title VIII, (2005)

United Nations General Assembly (1993) Resolution 48/104 Declaration on the Elimination of Violence against Women. New York: United Nations General Assembly.

U.S Bureau of the Census. (2002). The Asian Population (1990 and 2000U.S. Census Brief). In U.S Bureau of Census (Ed.): Government Printing Press.

Warrier, S. (2000). Social, Legal, and Community Challenges Facing South Asian Immigrant Women. In S. Nankani (Ed.), Breaking the Silence Domestic Violence in the South Asian-American Community (pp. 89-97): Xlibris Corporation.

workpermit.com. (2005). Dependent spouses of US H-1 visa holders often frustrated (pp. $1-3)$.

\section{Author's note:}

Address correspondence to: Shreya Bhandari, doctoral student, University of MissouriColumbia, School of Social Work, 708 Clark Hall, Columbia, Missouri 65211. E-mail: ssb7dd@mizzou.edu. 